\title{
Development of Fish Bars as a High Zinc and Calcium Snack Made from Bilih Fish (Mystacoleuseus padangensis Blkr) Flour
}

\author{
Deni Elnovriza $^{1 *}$, Hadi Riyadi ${ }^{2}$, Rimbawan $^{2}$, Evy Damayanthi $^{2}$, Adi Winarto ${ }^{3}$ \\ ${ }^{1}$ Department of Nutrition, Faculty of Public Health, Andalas University, Padang 25129, Indonesia \\ ${ }^{2}$ Department of Community Nutrition, Faculty of Human Ecology, IPB University, \\ Bogor 16680, Indonesia \\ ${ }^{3}$ Department of Anatomy, Physiology, and General, Faculty of Veterinary Medicine, \\ IPB University, Bogor 16680, Indonesia
}

\begin{abstract}
The study analysed differences in nutrition content of various bilih fish flour proportions in bilih fish bar with zinc and calcium as minerals of interest. The study used a Completely Randomized Design $(\mathrm{CRD})$. The proportion of bilih fish flour in the fish bars dough were of three levels, i.e. $30 \%, 40 \%$ and $50 \%$ of the total weight of flour. The data obtained were analyzed with one-way ANOVA, followed by Duncan's New Multiple Range test. The level of statistical significance was set at $p<0.05$. The best proportion based on its nutritional content was the $50 \%$ with the energy content of $327 \mathrm{kcal}$, protein content $22.75 \%$, lipid content $11.99 \%$, carbohydrate content $32.06 \%$, moisture content $28.28 \%$, ash content $4.44 \%$, zinc content $4.58 \mathrm{mg}$, and calcium content $922.23 \mathrm{mg}$ per $100 \mathrm{~g}$. A serving size $( \pm 30 \mathrm{~g})$ of treatment is able to suffice for $5.06-7.05 \%$ zinc and $0.87-16.77 \%$ calcium adequacy as well as the daily requirement of $2,150 \mathrm{kcal}$. Sensory evaluation showed that the treatments had no significant effects on the organoleptic attributes of the fish bars, except for taste (0.033). This bilih fish bar can be utilized as a source of zinc and calcium for high-risk groups such as children, adolescents, pregnant women, and people with diabetes.
\end{abstract}

Keywords: bilih fish, calcium, fish bars, fish flour, zinc

\section{INTRODUCTION}

Growth assessment is a sensitive indicator for the health and nutrition status of children under five years (Ejaz \& Latif 2010). Growth failure can be caused by insufficient intake of one or more nutrients, including micronutrients such as iron, zinc, and calcium.

Zinc is a trace element that affects various fundamental functions and processes in the human body. Zinc is essential for growth and development, enhancing immunity, reproduction, cognitive function, and vision. Zinc deficiency in humans is widespread throughout the world and groups that have high malnutrition risk generally respond to zinc supplementation (Riyadi 2007). The global prevalence of deficiency of zinc is approximately $17 \%$. Deficiency of zinc may impair growth and contribute to childhood stunting (Mayo-Wilson et al. 2014)

Calcium is an essential mineral that is only available to the body through food. Calcium plays a crucial role in various biological functions, both in the form of free ions or bound complexes (Peacock 2010). Calcium is a mineral needed in the formation of bones and teeth, heart function, blood vessel contraction, muscle func- tion, and hormone secretion. The prevalence of zinc and calcium deficiency in Indonesia is high, the prevalence of calcium deficiency in the adult population is $54.2 \%$, while for zinc deficiency is $35.5 \%$ based on the probability method and the prevalence of the calcium inadequacy is $63.9 \%$, and zinc is $42.1 \%$ base on CPM-100 (Prasetyo 2018).

The bilih fish (Mystacoleuseus padangensis Blkr) is a potential local food in West Sumatra contains high zinc and calcium. A preliminary study using different drying methods showed that bilih fish flour contained $14.56-23.38 \mathrm{mg}$ of zinc and $3495.00-4786.53 \mathrm{mg}$ of calcium per $100 \mathrm{~g}$ of dry basis. The lowest zinc and calcium content obtained from the direct sun drying method and the highest with the oven drying. Therefore Bilih fish can be used as an alternative for the source of zinc and calcium in the community.

Snack bars are versatile, practical, durable and convenient as well as can be packed with nutritional value. Snack bars are designed to provide nutrition for people with high mobility (on the go) and acquired various dietary needs (da-Silva et al. 2013). According to Aramouni \& Abu-Ghoush (2010) apart from energy bars, substitute-food bars, and low-carbohydrate bars,

"Corresponding Author: tel: +62811664715, email: denielnovriza@ph.unand.ac.id 
there are cereal bars, nutraceutical, diets and bars with the target of encountering the nutritional needs of diabetics, women and for children. Fish bars, bars made of fish, are a modified product from the snack bars that taste sweet and salty (savory) and in this study the ingredients was bilih fish.

There has been limited research on foods/ snacks high in zinc and calcium that utilizes local food. Therefore, development of bilih fish bar as a potential source of zinc and calcium is important due to the high prevalence of both zinc and calcium deficiencies. This study aims to analyse differences nutrient content and organoleptic attributes of the various proportion of bilih fish flour (Mystacoleuseus padangensis Blkr) in the fish bar production with zinc and calcium as two minerals of interest.

\section{METHODS}

\section{Design, location, and time}

This study was a laboratory experiment to develop fish bar product from bilih fish flour using a Completely Randomized Design (CRD), with the various proportion of bilih fish flour in the fish bars mix. The repetitions were done three times. The study conducted in the Laboratory of Technology and Engineering Process of Agricultural Products, Department of Technology in Agricultural Product, Faculty of Agricultural Technology, Andalas University. The study conducted in September-November 2016.

\section{Materials and tools}

The bilih fish was obtained from the fisherman in Singkarak Lake, Solok Regency. Protein content was determined through conventional nitrogen determination method using the Foss Tecator Kjeltec 8400. The lipid content was determined by direct extraction method using Soxhlet. The ash content used the gravimetric method using the electric furnaces at $550^{\circ} \mathrm{C}$. The moisture content determined by the gravimetric method uses an oven at $105^{\circ} \mathrm{C}$ by 3 hours). The total of carbohydrate content was calculated using the by difference.

The analysis of zinc used the hydrolysis method and measurement of the numeral of light absorbed by the atom using the Atomic Absorption Spectrophotometer/AAS). The calcium content was determined by the maximum metal emission intensity method using the Inductively Coupled Plasma-Optical Emission Spectrometer/ ICP-OES). Energy content was calculated based on the total of $\mathrm{kcal} / \mathrm{g}$ of lipid, protein, and carbohydrates.
Materials for the fish bars development namely bilih fish flour, rice flour, glutinous rice flour, skim milk, eggs, dark chocolate, raisins, sugar, margarine, roasted peanuts, cooking oil, vanilla, and water. The equipment used includes the ovens, mixers, baking tools/molds, and the material for chemical analysis.

\section{Procedures}

The fish flour production. Bilih fish was cleaned from the dirt and washed thoroughly, the bilih fish (all of the body and head) then steamed for 45 minutes and dried in an oven at $100^{\circ} \mathrm{C}$ for 5 hours. The dried Bilih fish was mashed-up with a dry blender, then sifted with a 60 mesh sieve (modified from Nandhani \& Yunianta 2015; Rahmi et al. 2018).

The fish bars production. Trials and errors to obtain acceptable sensory qualities for snacks resembling the taste, color, and texture of snack bars available in the market were done. It was concluded that the chosen formula to cover the fishy was the addition of chocolate, raisins, and roasted peanuts (Table 1 ).

Rice flour and white glutinous rice flour used in the flour mixture are in the ratio of 1:1. The proportion of bilih fish according to treatment in every $300 \mathrm{~g}$ of the total flour in the dough is calculated according to the proportion of each treatment of $30 \%, 40 \%$ and $50 \%$ of bilih fish flour respectively (Table 2). The fish bars was made by mixing solid ingredients of rice flour, glutinous rice flour, skim milk, salt, raisins, peanuts, and bilih fish flour with the binders that consist of egg white, cooking oil, water, sugar, margarine, and dark chocolate. After the mixture was ready, it was molded in a $15 \mathrm{~cm} \mathrm{x} 10 \mathrm{~cm} \times 1 \mathrm{~cm}$ baking plate to be baked in an oven at $160^{\circ} \mathrm{C}$ for $25 \mathrm{~min}-$ utes. After cooled down at room temperature for 30 minutes, finally, the bars are cut into $1.5 \mathrm{~cm} \mathrm{x}$ $10 \mathrm{~cm} \mathrm{x} 1 \mathrm{~cm}$ with a weight of $15 \mathrm{~g}$ each piece. One serving is consist of two pieces.

\section{Data analysis}

The data were analyzed using the $I B M$ SPSS Statistics Version 21. Data obtained from measurements of parameters obtained analyzed by one-way ANOVA followed by Duncan's new multiple range test. The level of statistical significance was set at $\mathrm{p}<0.05$.

\section{RESULTS AND DISCUSSION}

\section{The bilih fish flour}

There have been various food products which are made from fish to increase nutrients content of the food products such as biscuits, 
Table 1. Formula of fish bars

\begin{tabular}{lc}
\hline \multicolumn{1}{c}{ Material } & Ammount \\
\hline Flour (rice flour: glutinous white rice & $300 \mathrm{~g}$ \\
flour ratio is 1:1 + bilih fish flour) & \\
Skim milk powder & $20 \mathrm{~g}$ \\
Salt & $1 \mathrm{~g}$ \\
Egg white & 4 items \\
Water & $30 \mathrm{ml}$ \\
Sugar & $20 \mathrm{~g}$ \\
Roasted peanuts & $25 \mathrm{~g}$ \\
Raisins & $30 \mathrm{~g}$ \\
Margarine & $20 \mathrm{~g}$ \\
Dark chocolate & $50 \mathrm{~g}$ \\
Cooking oil & $4 \mathrm{~g}$ \\
\hline
\end{tabular}

Table 2. The proportion of bilih fish flour according to treatment in every $300 \mathrm{~g}$ of total flour

\begin{tabular}{lccc}
\hline \multicolumn{1}{c}{ Flour type } & $\begin{array}{c}\mathrm{A}=30 \% \\
(\mathrm{~g})\end{array}$ & $\begin{array}{c}\mathrm{B}=40 \% \\
(\mathrm{~g})\end{array}$ & $\begin{array}{c}\mathrm{C}=50 \% \\
(\mathrm{~g})\end{array}$ \\
\hline $\begin{array}{l}\text { Rice flour } \\
\text { Glutinous white }\end{array}$ & 105 & 90 & 75 \\
rice flour & 105 & 90 & 75 \\
Bilih fish flour & 90 & 120 & 150 \\
\hline
\end{tabular}

cookies, crackers, noodles, the snack puffs, baby puree, dietary food, and as food supplements (Mervina et al. 2012; Zuhri et al. 2014; Adawiyah \& Selviastuti 2014; Fatmawati \& Mardiana 2014; Arza \& Tirtavani 2017). Thus bilih fish flour also offers the same potential as it is also packed with nutrient.

A good quality fish flour contains $60-70 \%$ protein (Cho \& Kim 2010) as in bilih fish flour in our study it was around $61.28 \%$. The lipid content in the bilih fish flour in this study was quite high at $12.22 \%$; this may due to the skipping of the press-down process since pressing in addition to reducing the water will also causes fat and oil losses. This study found that the ash content of bilih fish flour was lower than anchovy flour which was $15.0 \%$ (Cho \& Kim 2010). Ash content shows the number of minerals contained in food ingredients. If the ash content is high, the mineral content is also high. The detailed composition of fresh bilih fish and bilih fish flour per $100 \mathrm{~g}$ used in this study is shown in Table 3.

\section{Sensory evaluation}

Color plays a vital role in food because if the color of a meal is not attractive or unusual, then even though it has good nutrient content,
Table 3. Nutritional composition of bilih fish per $100 \mathrm{~g}$

\begin{tabular}{lcc}
\hline \multirow{2}{*}{$\begin{array}{c}\text { Nutritional } \\
\text { composition }\end{array}$} & \multicolumn{2}{c}{ Bilih fish } \\
\cline { 2 - 3 } & Fresh & Flour \\
\hline Energy (kcal) & 85 & 364 \\
Protein (\%) & 17.33 & 61.28 \\
Lipid (\%) & 0.20 & 12.22 \\
Carbohydrate (\%) & 3.48 & 2.32 \\
Ash (\%) & 1.52 & 13.02 \\
Zinc (mg) & 4.76 & 20.061 \\
Calcium (mg) & 1128.05 & 4100.08 \\
Moisture (\%) & 77.47 & 11.16 \\
\hline
\end{tabular}

it will reduce consumer acceptance of the food. The color of the fish bars produced with the three treatments is the same, namely brown. The color of the fish bars that are most preferred by the panelists was treatment $\mathrm{B}$ with a value of 3.45 and the least preferred was in treatment $\mathrm{A}$ with the score of 3.23, in the range 1-5 (from dislike to very like) and there were no significant differences between treatments (Table 4).

The same with the flavor of bilih fish bars, it ranged from 2.32-3.00 on a scale of 1-5 from dislike to very like and the proportion of the use of bilih fish flour did not have a significant effect on the sensory value of aroma fish bars ( $p>0.05)$. While for texture, the score ranged from 2.863.32. The sensory value of the texture of fish bars favored by panelists in this study was highest in the $40 \%$ proportion of bilih fish. The ANOVA results showed that the percentage of bilih fish flour did not have a significant effect on the texture of the resulting fish bars ( $>0.05)$ (Table 4).

In contrast to other sensory attributes that seem do not affected by the proportion of Bilih fish flour added, the proportion of bilih fish flour proved to have a significant effect on the taste of the fish bars $(p<0.05)$. The average sensory value of the taste of fish bars ranges from 2.05 - 3.05 on a scale of 1-5 from dislike to very like, with the highest taste value in treatment $B$ and the lowest in treatment A. The overall sensory attributes evaluation showed that treatment $\mathrm{C}$ with the highest bilih fish flour content $(50 \%)$ did not show significant differences in sensory qualities compared to the $40 \%$ proportions (Table 4 ).

\section{The nutritional composition of fish bars made of bilih fish flour}

Energy. The study showed that the average energy content of the bilih fish bars was 327- 
Table 4. The average value of the sensory evaluation of fish bars made of bilih fish flour

\begin{tabular}{cccccc}
\hline Treatment & Color & Taste & Flavor & Texture & Overall \\
\hline $\mathrm{A}=30 \%$ & $3.23 \pm 0.97^{\mathrm{a}}$ & $2.05 \pm 1.09^{\mathrm{a}}$ & $2.32 \pm 1.04^{\mathrm{a}}$ & $2.86 \pm 1.28^{\mathrm{a}}$ & $2.41 \pm 1.00^{\mathrm{a}}$ \\
$\mathrm{B}=40 \%$ & $3.45 \pm 0.86^{\mathrm{a}}$ & $3.05 \pm 1.17^{\mathrm{b}}$ & $3.00 \pm 1.16^{\mathrm{a}}$ & $3.32 \pm 0.89^{\mathrm{a}}$ & $3.36 \pm 0.95^{\mathrm{b}}$ \\
$\mathrm{C}=50 \%$ & $3.27 \pm 0.99^{\mathrm{a}}$ & $2.68 \pm 1.46^{\mathrm{ab}}$ & $2.73 \pm 1.35^{\mathrm{a}}$ & $3.32 \pm 0.95^{\mathrm{a}}$ & $3.00 \pm 1.23^{\mathrm{ab}}$ \\
$\mathrm{p}$ & 0.699 & $0.033^{*}$ & 0.169 & 0.268 & $0.016^{*}$ \\
\hline
\end{tabular}

*One-way ANOVA followed by Duncan's New Multiple Range test $(\mathrm{p}<0.05)$. Means with similar superscript letter in one column are not significantly different $(\mathrm{p}>0.05)$. A, B, and C: proportion of bilih fish flour

$328 \mathrm{kcal} / 100 \mathrm{~g}$ (Table 5), which also showed no significant differences between the three treatments $(\mathrm{p}>0.05)$. The bilih fish bar in this study had lower energy content than the berangan banana with $455 \mathrm{kcal}$ (Ho et al. 2016). It was also lower than the tempeh and salak pondoh bar, which ranged from 456-498 kcal per $100 \mathrm{~g}$ (Pradipta 2011). However, energy content of bilih fish bars is higher than the energy content of the fish cake, which is $240 \mathrm{kcal}$ per $120 \mathrm{~g}$ (Ministry of Health Canada 2008) as well as from the tilapia waste flour bread which is $255-237$ kcal (Monteiro et al. 2018).

The amount of energy content of food depends on their fat, protein, and carbohydrate contents. The early years of life were a period of rapid growth, and the proper nutrients were essential during this period. Children who do not get enough energy and nutrients will not be able to maintain growth and development as expected (Stephen et al. 2012). Hence, energy content of the fish bars in this study were equal for $5.83 \%$ of energy per serving $( \pm 30 \mathrm{~g})$ or $29.14 \%$ per $100 \mathrm{~g}$ and in the category energy requirements of 2,150 kcal can satisfy $15.25 \%$ of per $100 \mathrm{~g}$ based on the food label reference for children 1-3 years with energy requirement $1,125 \mathrm{kcal}$ (BPOM 2016a).

Protein. The protein content of fish bars of bilih fish flour in this study ranged from $17.30 \%$ $22.75 \%$ (Table 5) and the were no significant differences between the treatments $(p>0.05)$. The protein level in the snack bars depends on the amount of protein-rich sources added. For example, the protein content of tempeh and salak pondoh snack bars is around $15.87 \%-23.66 \%$ and increases in line with the rise in the number of tempeh used in the production of the snack bars (Pradipta 2011). The protein content in the catfish crackers in the study of Azra \& Tirtavani (2017) was $12.53-16.10 \%$, which also positively associated with the amount of catfish flour added in the process. The bilih fish bar has a quite high protein content thus can be a alternative source of protein, especially in children and adolescents who need high protein to support their growth. Based on the nutritional label reference for children aged 1-3 years on protein intake of $26 \mathrm{~g}$, each serving of the fish bar $( \pm 30 \mathrm{~g})$ is equal to 13.31 $17.50 \%$ or $66.54-87.50 \%$ per $100 \mathrm{~g}$ of protein requirement (BPOM 2016a). Particular nutrients have a more significant effect on brain development than others; it includes protein, long chain PUFAs, zinc, iron, iodine. That macro dan micronutrients that are critical in brain development in the first 1000 days of life byc presenting both human and pre-clinical data that their significant impact (Cusick \& Georgieff 2016). In addition to its use for children and adolescent to support their growth, it can also be utilized as snacks for people with diabetes.

Protein can be used as a source of blood glucose in conditions of hypoglycemia to prevent hypoglycemia. Consumption of high protein meals in diabetes mellitus without kidney disease

Table 5. The means of the analysis of proximate and mineral of fish bars made of bilih fish flour per $100 \mathrm{~g}$

\begin{tabular}{|c|c|c|c|c|}
\hline \multirow{2}{*}{ Mean } & \multicolumn{3}{|c|}{ Treatment } & \multirow[b]{2}{*}{$\mathrm{p}$} \\
\hline & $A=30 \%$ & $\mathrm{~B}=40 \%$ & $\mathrm{C}=50 \%$ & \\
\hline Energy (kcal) & $329 \pm 8.66^{\mathrm{a}}$ & $327 \pm 5.95^{\mathrm{a}}$ & $327 \pm 9.01^{\mathrm{a}}$ & 0.994 \\
\hline Protein $(\%)$ & $17.30 \pm 0.64^{\mathrm{a}}$ & $18.94 \pm 1.78^{\mathrm{a}}$ & $22.75 \pm 0.86^{\mathrm{b}}$ & $0.004 *$ \\
\hline Lipid (\%) & $10.70 \pm 0.44^{\mathrm{a}}$ & $10.98 \pm 0.42^{\mathrm{ab}}$ & $11.99 \pm 0.74^{\mathrm{b}}$ & $0.060 *$ \\
\hline Carbohydrate $(\%)$ & $40.57 \pm 0.79^{a}$ & $38.19 \pm 1.25^{\mathrm{b}}$ & $32.06 \pm 0.30^{c}$ & $0.000 *$ \\
\hline Moisture (\%) & $28.06 \pm 1.95^{\mathrm{a}}$ & $28.01 \pm 1.08^{\mathrm{a}}$ & $28.28 \pm 1.47^{\mathrm{a}}$ & 0.823 \\
\hline Ash $(\%)$ & $3.34 \pm 0.29^{\mathrm{a}}$ & $3.38 \pm 0.09^{\mathrm{ab}}$ & $4.44 \pm 0.43^{\mathrm{b}}$ & $0.012 *$ \\
\hline Zinc (mg) & $3.29 \pm 0.82^{\mathrm{a}}$ & $4.50 \pm 2.83^{b}$ & $4.58 \pm 2.43^{\mathrm{b}}$ & $0.001 *$ \\
\hline Calcium (mg) & $597.61 \pm 26.93^{\mathrm{a}}$ & $858.34 \pm 92.54^{\mathrm{b}}$ & $922.23 \pm 44.10^{\mathrm{b}}$ & $0.001 *$ \\
\hline
\end{tabular}

*One-way ANOVA followed by Duncan's New Multiple Range test $(\mathrm{p}<0.05)$. Means with similar superscript letter in one column are not significantly different $(\mathrm{p}>0.05)$. A, B, and C: proportion of bilih fish flour 
is recommended to reduce spikes in blood glucose level. High total protein intake was related toT2DM risks. Dietary protein is important modulators of glucose homeostasis by promoting insulin resistance and increasing gluconeogenesis, although high protein diet has shown beneficial effect on glucose homeostasis in short term trials (Ke et al. 2018) For people with type 2 DM, aiming for $20-30 \%$ of total energy intake as protein is the goal. This amount of protein intake can be beneficial by improving glycemic control, preservation of lean body mass during weight loss in diabetes (Campbell \& Rains 2015).

Carbohydrate. Carbohydrates have an essential role in determining the characteristics of food items such as color, taste, texture, and others. The primary function of carbohydrates is as a source of energy for the body and is very important for growth and development. Carbohydrate are the primary source of calories for almost all the world's population.

This study shows that the proportion of different bilih fish flour will provide different carbohydrate level, and the treatment has a statistically significant effect $(p<0.05)$. The carbohydrate content of this study is lower than the energy bars in the study by Ho et al. (2016), which is $56.89 \%$. The more bilih fish flour added, the lower the carbohydrate in the fish bars. It is almost the same the tempeh and salak pondoh snack bars, which have $33.97 \%$ and $42.64 \%$ carbohydrate content, where the more tempeh added, the lower the carbohydrate level (Pradipta 2011).

Based on the reference of nutritional on a food label, the carbohydrates requirement for the general population is $325 \mathrm{~g}$, and in children aged 1-3 years is $155 \mathrm{~g}$ (BPOM 2016a), the total carbohydrate content of each serving of the bilih fish bars is equal to $1.97-2.50 \%$ and $4.14-5.23 \%$ of it. The low carbohydrates and energy content of bilih fish bars made it possible to recommend for people who want to lose weight and in people with diabetes. According to Rafkin-Mervis and Marks (2001), the diabetic food bars that are circulating in the market are mostly formulated to reduce the incidence of postprandial hyperglycemia and prevent hypoglycemia. Williams et al. (2006) reported that snack bars with high protein/carbohydrate ratios could improve the post-meal glucose profiles and diurnal glucose in Type 2 Diabetes Mellitus (T2DM) patients and insulin resistance. In this study, the ratio of protein:carbohydrate is $0.43: 0.71$, shows that the higher the proportion of Bilih fish flour used, the higher the rate of protein:carbohydrate.

Lipid. The average lipid content of the bilih fish bar was $10.70 \%-11.99 \%$ and there were no significant differences between all treatments $(\mathrm{p}>0.05)$. Lipid content in this study was lower than tempeh and salak pondoh in Pradipta's study (2011), those are $18.77 \%$ and $24.88 \%$, as well as research by Ho et al. (2016) who reported that the berangan bananas bar also had higher lipid levels of $22.39 \%$. In this study, the higher the proportion of bilih fish flour used, the higher the lipid content. In the research of Pradipta (2011), the addition of tempeh also increased the lipid content of the snack bars produced, where tempeh flour contained $22.7 \%$ lipid.

Fish, including bilih fish, are good sources of unsaturated fatty acids which have a positive effect on dyslipidemia and heart disease. Anchovy known to contain 19 types of fatty acids consisting of 10 Saturated Fatty Acids (SFA), 3 Monounsaturated Fatty Acids (MUFA), and 6 Polyunsaturated Fatty Acids (PUFA) (Siagian 2017). The Ministry of Health of Canada (2008) stated that every $120 \mathrm{~g}$ of fish cake contains 12 $\mathrm{g}$ of fat, $3.3 \mathrm{~g}$ of SFA, $2.6 \mathrm{~g}$ of PUFA, $0.10 \mathrm{~g}$ of DHA, and $63 \mathrm{mg}$ of cholesterol. Studies indicate that fat quality also may affect insulin sensitivity and hence, the risk of T2DM. Study of Telle-Hansen et al. (2019) have identified that beneficial effect of both marine and vegetablederived PUFAs on glycemic control in people with T2DM. In prospective cohort studies, dietary intake of total fat, SFA and MUFA were not associated with diabetes incidence, higher PUFA intakes were associated with a lower or no risks of diabetes (Wanders et al. 2017)

Moisture. Water is an essential component of food ingredients because it can affect the appearance and taste of food as well as critical in determining the durability of food because it affects the physical, chemical, microbiological changes, and enzymatic changes. The moisture content of the bilih fish bars in this study was $28.01 \%-28.28 \%$ and the proportion of bilih fish flour did not significantly affect the levels of moisture of the fish bars ( $>>0.05)$. The moisture content in this study is higher than the standards of snack bars in Pradipta (2011), that is $15.11 \%$ $-20.72 \%$, but lower than the Monteiro et al. (2018), that is $36.09-42.39 \%$.

The high moisture content in the bilih fish bars in all treatments indicates high water activity $\left(\mathrm{a}_{\mathrm{w}}\right)$ thus causes the food products be less durable and easily damaged. There is a linear relationship between moisture content with $\mathrm{a}_{\mathrm{w}}$, the higher the moisture content, the higher the $\mathrm{a}_{\mathrm{w}}$ value (Leviana \& Paramita 2017). Foods that have a high content or value of $a_{w}$ are generally rapidly spoiled, either due to microbial growth or due to specific chemical reactions such as oxidation and enzymatic reactions. Therefore, solution is needed to extend the shelf life of bilih fish 
products, such as increasing the time of roasting of fish stems and reducing it temperature to reduce moisture content or by adding antioxidants to reduce microbial damage caused by the high moisture and lipid content.

$\boldsymbol{A s h}$. Ash content is one of the factors that determine the quality of food. If the ash level is high, the mineral content is also high. The average level of ash in the bilih fish bars ranged from $3.34-4.44 \%$ and the differences were statistically significant $(p<0.05)$ between treatments. In this study, it shows that the higher the proportion of bilih fish flour, the higher the ash content of the fish bars, which in line with the increase in the mineral content.

Zinc. The zinc content of the fish bars of bilih fish flour in this study is $3.29-4.58 \mathrm{mg} / 100$ $\mathrm{g})$ and the differences were significant between treatments $(p<0.05)$. The zinc content in this study is quite high, shows that the zinc content for each serving $( \pm 30 \mathrm{~g})$ can meet $7.59-10.56 \%$ of zinc requirements in $2,150 \mathrm{kcal}$ energy requirement (13 mg) and 24.68-34.35\% for children age 1-3 years with $4 \mathrm{mg}$ of zinc requirements (BPOM 2016a). Zinc content in the bilih fish bar is higher than beef $(4.1 \mathrm{mg})$, cork fish $(0.4 \mathrm{mg})$, tuna (1.6 $\mathrm{mg})$, chicken eggs $(1.5 \mathrm{mg})$, duck eggs (1.8 mg), and chicken meat $(1.8 \mathrm{mg})$ in per $100 \mathrm{~g}$.

Various studies show that zinc deficiency is significantly associated with stunting. Zinc deficiency may affects numerous organ system incuding immune, skeletal, central nervous systems (Mayo-Wilson et al. 2014). Zinc also a potent bone tissue growth stimulator that stimulates bone metabolism and bone protein synthesis. Zinc have a stimulatory effect on osteoblastic bone formation and mineralization. Bone growth retardation is a common finding in various conditions associated with dietary zinc deficiency. Bone zinc content has been shown to decrease in aging, unloading of skeletal, and conditions of postmenopauseal, suggesting its role in bone disorder (Yamaguchi 2010).

Human studies suggest that maternal zinc deficiency during pregnancy can cause adverse outcomes of pregnancy for the mother and fetus, fetal growth retardation, embryonic or fetal death and early postnatal infant immune system (Hess \& King 2009). Sun et al. (2009) found that higher zinc intake associated with a lower risk of DM in US women. Study of Vashum et al. (2013) in Australia showed that high zinc intakes and high zinc:iron ratios were associated with a lower risk of T2DM, so that zinc supplements could reduce the risk of T2DM.

The food claim as a source of zinc should meet no less than $15 \%$ of the nutritional label amount per $100 \mathrm{~g}$ (BPOM 2016b). Thus the bi- lih fish bar full filled the claim as a zinc source food and can be recommended as a source of zinc for the people which requires large amounts of zinc, especially in children, adolescents, pregnant women, and people with diabetes.

Calcium. Calcium content of fish bars in this study ranged from 597.61 to $922.23 \mathrm{mg}$. The ANOVA showed that the proportion of bilih fish flour had a significant effect on the calcium content of the fish bars $(\mathrm{p}<0.05)$. This result is higher than the calcium of cookies with $25 \%$ tempeh flour substitution and 10\% anchovy flour, which is $53.93 \%$ (Rahmawati 2013). Calcium for each serving $( \pm 30 \mathrm{~g})$ can provide approximately $16.29-25.15 \%$ of the calcium requirement for an adult group with $2,150 \mathrm{kcal}(1,100 \mathrm{mg})$ and in children aged $1-3$ years $(650 \mathrm{mg})$ sufficiently for as much as 27.58-42.56\% (BPOM 2016a). Thus the bilih fish bars can be utilized as a source of calcium in groups at risk for calcium deficiency.

Calcium as a nutrient is most often associated with bone formation and metabolism. Low calcium consumption is related to osteoporosis. Calsium is important not only the skeletal, but also muscle concentarstion, heartbeat regulation, nerve impulse transmission, regulation of blood pressure and immune function and other critically important physiologic processes. Calsium also take on an increasingly critical role in the maintenance of skeletasl integrity in menopause women (Lorincz et al. 2009). Calsium supplementation in pregnancy has the potential to reduce adverse outcomes of gestational. In particularly by decreasing the risk of developing hypertensive disorders, which are associated with a significant number of maternal death and considerable rosk o preterm birth (Kumar \& Kaur 2017). Besides that, the study of Mitri et al. (2011) found that consumption of calcium 600-1,000 mg per day had a beneficial effect on diabetes. Consumption of calcium-rich foods is also associated with a reduced risk of incident T2DM, where the intake of $>1,200 \mathrm{mg}$ per day decreases the risk of T2DM by $33 \%$ compared to $<400 \mathrm{IU}$ (Pittas et al. 2007).

\section{CONCLUSION}

The $50 \%$ proportion of fish flour for the Bilih fish bars was chosen as the best treatment based on the proximate analysis and analysis of zinc and calcium content of the fish bars by considering the needs of specific groups such as child-ren and the general population. In addition, the $50 \%$ proportion of bilih fish flour did not show a significant difference in the overall organoleptic attribute test compared to the $40 \%$ proportion. Thus, the $50 \%$ proportion was chosen as best the bilih fish bars. 
The bilih fish bars can be utilized as zinc and calcium food source in groups at risk of suffering from zinc and calcium deficiencies, namely children, adolescents, pregnant women, and people with DM. Further, it is necessary to examine the fatty acid content, levels of other minerals, and vitamins from the bilih fish bars as well as to find solutions to extend the shelf life of the Bilih fish bar products such as by increasing the time of roasting of fish stems and reducing it temperature to reduce moisture content or by adding antioxidants to reduce microbial damage caused by the high moisture and lipid content.

\section{ACKNOWLEDGEMENT}

This research is part of the author's dissertation at the Doctoral Program of the IPB University. The author would like to thank the Faculty of Public Health of Andalas University for giving a grant for this research. The authors have no conflict of interest.

\section{REFERENCES}

[BPOM RI] Badan Pengawas Obat dan Makanan Republik Indonesia. 2016a. Peraturan Kepala Badan Pengawas Obat dan Makanan Republik Indonesia Nomor 9 tahun 2016: Acuan Label Gizi. Jakarta: BPOM RI.

[BPOM RI] Badan Pengawas Obat dan Makanan Republik Indonesia. 2016b. Peraturan Kepala Badan Pengawas Obat dan Makanan Republik Indonesia Nomor 13 tahun 2016. Pengawasan Klaim pada Label dan Iklan Pangan Olahan. Jakarta: BPOM RI.

Adawiyah AR, Selviastuti R. 2014. Serburia suplemen tulang ikan bendeng dengan cangkang kapsul alginate untuk mencegah osteoporosis. Jurnal Ilmiah Mahasiswa 4(1):53-59.

Aramouni FM, Abu-Ghoush MH. 2010. Physicochemical and sensory characteristics of no-bake wheat-soy snack bars. J Sci Food Agric 1(1):44-51. Doi: 10.1002/isfa.4134.

Arza PA, Tirtavani M. 2017. Pengembangan crackers dengan penambahan tepung ikan patin (Pangasius hypophthalmus) dan tepung wortel (Daucus carota L). J Nutr Food Res 40(2):55-62.

Campbell AP, Rains TM. 2015. Dietary protein is important in the practical management of prediabetes and type 2 diabetes. J Nutr 145(1):164S-169S.

Cho JH, Kim IH. 2010. Fish meal-nutritive value. J Anim Physiol Anim Nutr 95(2011):685692.
Cusick SE, Georgieff MK. 2016. The role of nutrition in brain development: the golden opportunity of the "first 1000 days". J Pediatr 175:16-21. Doi:10.1016/j. jpeds.2016.05.013.

Da Silva EP, Siqueira HH, do Lago RC, Rosell CM, Boas EVBVB. 2013. Developing fruit-based nutritious snack bars. J Sci Food Agric 94(1):52-56. Doi: 10.1002/ jsfa.6282.

Ejas MS, Latif N. 2010. Stunting and micronutrient deficiencies in malnourished children. J Pak Med Assoc 60(7):543-547.

Fatmawati, Mardiana. 2014. Tepung ikan gabus sebagai sumber protein (food supplement). Bionature 15(1):54-60.

Ho LH, Tang JYH, Akma SM, Aiman HM, Roslan A. 2016. Development of novel "energy" snack bar by utilizing local Malaysian ingredients. Inter Food Res J23(5):2280-2285.

Hess SY, King JC. 2009. Effects of maternal zinc supplementation on pregnancy and lactation outcomes. Food Nutr Bull 30(1):S61S78.

Ke Q, Chen C, He F, Ye Y Bai X, Cai L, Xia M. 2018. Association between dietary protein intake and tipe 2 diabetes varies by dietary pattern. Diabetol Metab Syndr 10(48):10pp.

Kumar A, Kaur S. 2017. Calsium: nutrient in pregnancy. J Obstetr Gynecol India 67(5):313-318.

Leviana W, Paramita V. 2017. Pengaruh suhu terhadap kadar air dan aktivitas air dalam bahan pada kunyit (Curcuma longa) dengan alat pengering electrical oven. METANA 13(2):37-44.

Lorincz C, Manske SL, Zernicke R. 2009. Bone health: part 1, nutrition. Sports Health 1(3):253-260.

Mayo-Wilson E, Junior Ja, Indad A, Dean S, Chan XHS, Chan ES,Jaswal A, Buttha ZA. 2014. Zinc supplementation for preventing mortality, morbidity and growth failure in children aged 6 months to 12 years of age. Intervention Review. Cochrane Database of Systematic Reviews 5(CD009384): 1-442. Doi: 10.1002/14651858.CD0099384.pub2

Mervina, Kusharto CM, Marliyati SA. 2012. Formulasi biskuit dengan substitusi tepung ikan lele dumbo (Clarias garispi$n u s$ ) dan isolate protein kedelai (Glicine max) sebagai makanan potensial anak balita gizi kurang. J Teknol Ind Pangan XXIII(1):9-16. 
Ministry of Health Canada. 2008. Nutrient value of some common foods. Publications Health Canada Ottawa, Ontario. www. healthcanada.gc.ca/cnf.

Mitri J, Hughes BD, Hu Fb, Pittas AG. 2011. Effects of vitamin D and calcium supplementation on pancreatic $\beta$ cell function, insulin sensitivity and glycemia in adults at high-risk on diabetes: The calcium and vitamin D for diabetes mellitus (CaDDM) randomized controlled trial. Am J Clin Nutr 94(2):486-894.

Monteiro MLG, Marsico ET, Junior MSS, Deliza R, de Oliviera DCR, Junior CAC. 2018. Tilapia-waste flour as a natural nutritional replacer for bread: A consumer perspective. PLoS ONE 13(5):e0196665.

Nandhani SD, Yunianta. 2015. Pengaruh tepung labu kuning, tepung lele dumbo, natrium bikarbonat terhadap sifat fisiko, kimia organoleptic cookies. J Pangan \& Agroind 3(3):918-927.

Peacock M. 2010. Calcium metabolism in health and disease. Clin J Am Soc Nephrol 5(Supp11):S23-S30. Doi: 10.2215/ CJN.05910809

Pittas AG, Harris SS, Stark PC, Huges BD. 2007 The effect of calcium supplementation on blood glucose and markers of inflammation in nondiabetic adults. Diabetes Care 30(4):980-986.

Pradipta I. 2011. Karakteristik fisikokimia dan sensoris snack bars tempe dengan penambahan salak pondoh kering. [Undergraduate Thesis]. Surakarta: Universitas Sebelas Maret.

Prasetyo TJ. 2018. Prevalensi defisiensi asupan gizi mikro penduduk dewasa Indonesia menggunakan metode probabilitas serta elastisitas konsumsi pangan. [Thesis]. Bogor: Institut Pertanian Bogor.

Rafkin-Mervis LE, Marks JB. 2001. The science of diabetic snack bars: A review. Clinical Diabetes 19(1):4-12.

Rahmawati H. 2013. Pengaruh substitusi tepung tempe dan tepung ikan teri nasi (Stolephorus sp) terhadap kandungan protein, kalsium, dan organoleptik cookies. Artikel Penelitian. Semarang: Program Studi Ilmu Gizi Fakultas Kedokteran Universitas Diponegoro.

Rahmi Y, Widya N, Anugerah PN, Tanuwijaya LK. 2018. Tepung ikan teri nasi (Stoleporus commersini Lac.) sebagai sumber kalsium dan protein pada corn flakes al- ternatif sarapan anak usia sekolah. Nutrire Diaita 10(1):34-44.

Riyadi H. 2007. Seng untuk Pertumbuhan dan Perkembangan Anak. Penanggulangan Masalah Defisiensi Seng (Zn): From Farm to Table. Bogor: Institut Pertanian Bogor.

Telle-Hansen VH, Gaundal L, Myhrstad MCW. 2019. Polyunsaturated fatty acids and glycemic control in type 2 diabetes. Nutrient 11(1067):18pp. Doi: 10.3390/nu11051067.

Siagian MI. 2017. Proksimat, asam lemak, kolesterol dan jaringan daging ikan teri (Stolephorus sp) segar dan goreng. [Undergraduate Thesis]. Bogor: Institut Pertanian Bogor.

Stephen A, Alles M. de Graaf C, Fleith M, Hadjilucas E, Isaacs E, Maffeis C, Zeinstra G, Matthyis C, Gil A. 2012. The role and requirements of digestible dietary carbohydrates in infants and toddlers. Eu J Clin Nutr 66(7):765-779.

Sun Q, van Dam RM, Willet WC, Hu FB. 2009. Prospective study of zinc intake and risk of type 2 diabetes in women. Diabetes Care 32: 629-634.

Vasum KP, McEvoy M, Shi Z, Milton AH, Islam MR, Sibbritt D, Patterson A, Byles J, Loxton D dan Attia J. 2013. Is dietary zinc protective for type 2 diabetes? Results from the Australian longitudinal study on women's health. BMC Endocr Disorders 13(1):1-8. DOI:10.1186/1472-6823-1340.

Wanders AJ, Alssema M, de Koning EJP, Cessie SI, de Vries JH, Zock PL, Rosendaal FR, den Heijer M, de Mutsert R. 2017. Fatty acid intake and its dietary souces in relation with markers of type 2 diabetes risks: the NEO study. Eur J Clin Nutr 71:245251.

Williams G, Noakes M, Keogh J, Foster P. and Clifton, P. 2006. High protein high fiber snack bars reduce food intake and improve short term glucose and insulin profiles compared with high fat snack bars. Asia Pacific J Clin Nutr 15(4):443-450.

Yamaguchi M. 2010. Role of nutritional zinc in the prevention of osteoporosis. Molec Cell Biochem 338(1-2):241-254.

Zuhri NM, Swastawati F, Wijayanti I. 2014. Pengkayaan kualitas mi kering dengan penambahan tepung daging ikan lele dumbo (Clarias gariepinus) sebagai sumber protein. Jurnal Pengolahan dan Bioteknologi Hasil Perikanan 3(4):119126. 